\title{
ORGANIZUOTOJE FIZINĖJE VEIKLOJE DALYVAUJANČIŲ VILNIAUS UNIVERSITETO STUDENČIŲ MITYBOS YPATUMAI
}

\author{
Laimutė Samsonienė ${ }^{1}$, Ramunẻ Žilinskiene் ${ }^{1}$, Marius Baranauskas ${ }^{1,2}$, Rimantas Stukas ${ }^{1}$ \\ Vilniaus universitetas ${ }^{1}$, Vilnius, Lietuvos olimpinis sporto centras ${ }^{2}$, Vilnius, Lietuva
}

\begin{abstract}
Laimutė Samsonienė. Biomedicinos (visuomenés sveikatos) daktaré. Vilniaus universiteto Sveikatos ir sporto centro docentė. Mokslinių tyrimų kryptis - visuomenės sveikata, i̇vairių socialinių grupių gyvenimo kokybẻs tyrimai, taikomoji fizinè veikla.
\end{abstract}

\section{SANTRAUKA}

Tyrimo tikslas - ištirti ir ìvertinti organizuotoje fizineje veikloje dalyvaujančiu antro, trečio ir ketvirto kurso Vilniaus universiteto studenčiu mityba.

Vadovaudamiesi PSO rekomenduojama gyventoju faktinès mitybos apklausos metodika ištyrème ir ìvertinome 128 Vilniaus universiteto studenčiu, pasirinkusiu laisvaji dalykq „Lvadas i kūno kultūra“", mityba. Tyrimo metu taikytas 24 valandu 1 dienos apklausos metodas. Vadovaujantis maisto produktu cheminès sudèties lentelèmis, apskaičiuota maisto raciono cheminè sudètis ir energinè verté. Duomenu statistine analizé atlikta naudojant „SPSS v.13 “ statistine programa. Tyrimo duomenu analizei atlikti taikyti matematinès statistikos metodai: skaičiuoti aritmetiniai vidurkiai $(\bar{x})$, duomenu sklaida vertinta pagal standartini nuokrypi (S). Siekiant kuo didesnio tikslumo ir ieškant statistiniu koreliaciniu ryšiu tarp kintamuju, skaičiavimams atlikti naudotas Pirsono (Pearson) koreliacijos koeficientas (r), kai $p \leq 0,05$.

Gauti tyrimo rezultatai lyginti su rekomenduojamomis paros maistiniu medžiagu ir energijos normomis, skirtomis moterims, kuriu fizinis aktyvumo koeficientas 1,5.

Tyrimo rezultatai parodè, kad studenči u su maistu gaunama energinè vertè $1696 \pm 611$ kcal yra per maža, lyginant su rekomenduojama $1950 \mathrm{kcal}$. Antro ir ketvirto kurso studenčiu maisto raciono energinè vertè kai kuriais atvejais ypač maža, individualiais atvejais vos siekè $586 \mathrm{kcal}$, o ketvirto — $663 \mathrm{kcal}$.

Pagrindinès moteru maisto maistinès medžiagos yra nesubalansuotos. Per didelę tiekiamos energinès vertès dali sudaro riebalai, per maža - angliavandeniai. Per didele energinès vertès dali sudaro riebalai $(40,2 \pm 9,2 \%)$, sočiosios riebalu rügštys (13 $\pm 4,7 \%)$, linolo riebalu rūgštis $(6,2 \pm 3,3 \%)$, mono ir disacharidai $(22,3 \pm 9,1 \%)$, per mažq — angliavandeniai (45,2 $\pm 9,9 \%)$, iš ju krakmolas ir kiti polisacharidai, polinesočiosios riebalu rügštys (6,9 3,6), iš ju — organizme nesintezuojama linoleno riebalu rūgštis $(0,4 \pm 0,4)$.

Tirtu studenčiu gaunamu baltymu kiekis atitinka rekomenduojama paros normq. Nepakeičiamos aminorügštys valinas, leucinas ir izoleucinas visu kursu studenčiu maiste yra nesubalansuotos. Antro kurso studenčiu maisto racione nesubalansuotos aminorūgštys metioninas ir lizinas.

Studenčiu maisto racione trūksta maisto produktu, kuriu sudètyje daug krakmolo ir kitu polisacharidu, skaiduliniu medžiagu (¿̀vairiu grüdiniu produktu, duonos ir batono kepiniu, šviežiu vaisiu ir daržoviu), daug baltymu turinčiu maisto produktu (mésos, žuvies, pieno produktu), todèl jos su maistu nepakankamai gauna mineraliniu medžiagu kalio, magnio, cinko, geležies ir vitaminu $A, D, B_{1}, B_{12}, E, P P$ ir folio rügšties.

Sveikatos ir sporto centre organizuotas fizinès veiklos pratybas lankančios studentès fizini aktyvuma ir mitybq derina netinkamai.

Raktažodžiai: maisto racionas, mityba, fizinis aktyvumas, energinè vertè, riebalai, angliavandeniai, baltymai, vitaminai, mineralinès medžiagos.

\section{IVADAS}

$\mathrm{S}$ veika ir visavertė mityba, tinkamas fizinis krūvis lemia žmogaus fizinę ir protinę raidą, ilgaamžiškumą, sveikatą. Šiandien akivaizdu, kad vienas pagrindiniu sveikatą lemiančiu ir ligų riziką mažinančių veiksnių yra sveika mityba (Škèmienè ir kt., 2007). Mitybos specialistai pabrěžia, kad mityba turi ne tik tausoti sveikatą, bet ją itvirtinti ir stiprinti (Stukas, Šurkienè, 1999; Stukas ir kt., 2000, 2009). Sveikata labiau sustiprinama tada, kai sveika mityba tinkamai derinama su organizuotomis fizinès veiklos pratybomis, nes fizinis aktyvumas lemia skirtingą žmogaus organizmo poreiki maistinems ir biologiškai aktyvioms medžiagoms. 
Sportininku mityba tyrinejjantys mokslininkai (Baranauskas ir kt., 2009; Stukas ir kt., 2009) akcentuoja, kad esant dideliems fiziniams krūviams sportininku organizmo poreikis su maistu gaunamai energinei vertei, baltymams, riebalams ir ypač angliavandeniams padidèja, tačiau atkreipia dèmesi i tai, kad nepriklausomai nuo kultivuojamos sporto šakos sportininkų mityboje trūksta angliavandenių, ypač krakmolo ir kitu polisacharidu, o riebalų kiekis viršija rekomenduojama.

Studentiškas amžius - vienas svarbiausių su mokymusi susijusios asmenybès raidos tarpsnių, kai nuolat patiriama itampa, reikia dideliu valios ir emociniu pastangų. Labai svarbu, kad studentai fizinę veiklą tinkamai derintu su mityba ir taip stiprintų, saugotų savo sveikatą bei išvengtų dẻl fizinès veiklos galimų organizmo pažeidimų. Todèl organizuotas fizinès veiklos pratybas lankantiems studentams svarbu kasdien su maistu gauti jų organizmui reikalingą pagrindinių maistinių medžiagų, vitaminų ir mineralinių medžiagų kiekį. Deja, dažnai dél studijų metu nuolatos patiriamos itampos studentams pritrūksta laiko pavalgyti, sutrinka juc mitybos režimas, pablogeja sveikata, o treniruotis darosi sunkiau, greičiau pajuntamas nuovargis (Maskeliūnas ir kt., 1996; Stukas, Šurkienè, 1999; Stukas ir kt., 2000).

Taigi, siekiant sustiprinti studentu sveikata ir skatinti PSO rekomenduojamus mokslinius tyrimus studentų sveikatos stiprinimo klausimais, labai aktualu ištirti ir įvertinti organizuotas fizinès veiklos pratybas lankančių studentu mitybą, kuri Lietuvoje per pastaraji dešimtmetị dar netirta.

Tyrimo tikslas - ištirti ir ịvertinti organizuotoje fizinejje veikloje dalyvaujančiu antro, trečio ir ketvirto kurso Vilniaus universiteto studenčiu mityba.

\section{TYRIMO METODIKA}

Autoriai, vadovaudamiesi PSO rekomenduojama gyventojų faktinės mitybos apklausos metodika, atliko 24 valandų studenčiu faktinès mitybos apklausą. 2009 metais ištirta ir Vilniaus universiteto Sveikatos ir sporto centre iqvertinta organizuotas fizinès veiklos pratybas lankančių antro, trečio ir ketvirto kurso studenčiu ( $(n=128)$, pasirinkusiu laisvaji dalyką „Ivadas ị kūno kultūrą“, mityba.

Vadovaujantis maisto produktų cheminès sudèties lentelèmis, apskaičiuota maisto raciono cheminè sudètis ir energinè vertè (Sučilienè, Abaravičius, 2002). Rekomendacijos remiasi siūlomomis paros maistinių medžiagų ir energijos normomis moterims, kuriu fizinio aktyvumo koeficientas 1.5 (Rekomenduojamos paros maistiniu medžiagu ir energijos normos, 2002). Duomenys statistiškai apdoroti naudojant SPSS v.13 statistinę programa. Tyrimo rezultatai palyginti su rekomenduojamomis paros maistinių medžiagų ir energijos normomis.

Tyrimo duomenų analizei atlikti taikyti matematinès statistikos metodai: skaičiuoti aritmetiniai vidurkiai $(\bar{x})$, duomenu sklaida vertinta pagal standartini nuokrypi (S). Siekiant kuo didesnio tikslumo ir ieškant statistinių koreliacinių ryšių tarp kintamujų, skaičiavimams atlikti naudotas Pirsono (Pearson) koreliacijos koeficientas (r), kai $\mathrm{p} \leq 0,05$.

\section{REZULTATAI}

Tyrimo rezultatai (1 lent.) parodè, kad studenčių su maistu gaunama energinè verte, vidutiniškai sudaranti $1696 \pm 611 \mathrm{kcal}$, yra per maža palyginus su rekomenduojama $1950 \mathrm{kcal}$. Antro ir ketvirto kurso studenčių maisto raciono energinè vertè kai kuriais atvejais ypač maža. Antro kurso moteru paros maisto raciono mažiausia energinè vertė kai kuriais individualiais atvejais vos siekè $586 \mathrm{kcal}$, ketvirto - $663 \mathrm{kcal}$.

Moteru maiste pagrindinès maistinès medžiagos nesubalansuotos. Per didelę energinès vertès dali sudaro riebalai $(40,2 \pm 9,2 \%)$, sočiosios riebalų rūgštys $(13 \pm 4,7 \%)$, linolo riebalų rūgštis $(6,2 \pm 3,3 \%)$, mono ir disacharidai $(22,3 \pm 9,1 \%)$, per mažą - angliavandeniai $(45,2 \pm 9,9 \%)$, iš ju krakmolas ir kiti polisacharidai, polinesočiosios riebalų rūgštys $(6,9 \pm 3,6)$, o iš jų — organizme nesintezuojama linoleno riebalų rūgštis $(0,4 \pm 0,4)$. Baltymų tiekiamos energinès vertès procentas, vidutiniškai sudarantis $14,6 \pm 4,9$, atitinka rekomenduojamą $(10-15 \%)$.

Moterų maisto raciono mažesnè angliavandenių tiekiama energinè dalis yra susijusi su ribotu maistu, kurio sudettyje yra daug angliavandeniuc, iš jų mono ir disacharidų $(r=0,59, \mathrm{p}<0,0001)$. Tačiau didesni riebalų tiekiamos energinès vertès procentą sudaro riebalu $(r=0,50 ; p<0,0001)$, $\mathrm{o}$ iš jų sočiuju riebalų rūgščių kiekis $(\mathrm{r}=0,43$; $\mathrm{p}<0,0001)$ maiste.

Baltymų kiekis studenčiu maiste, vidutiniškai sudarantis $59,9 \pm 23,3 \mathrm{~g}$, mažai didesnis už rekomenduojamą paros normą (49 g) (2 lent.). Nors nepakeičiamų aminorūgščių maiste netrūksta, tačiau kai kurios iš jų nesubalansuotos. Nustateme metionino ir lizino disbalansą antro kurso studenčių maiste. Jị patvirtina aminorūgščių santykis 


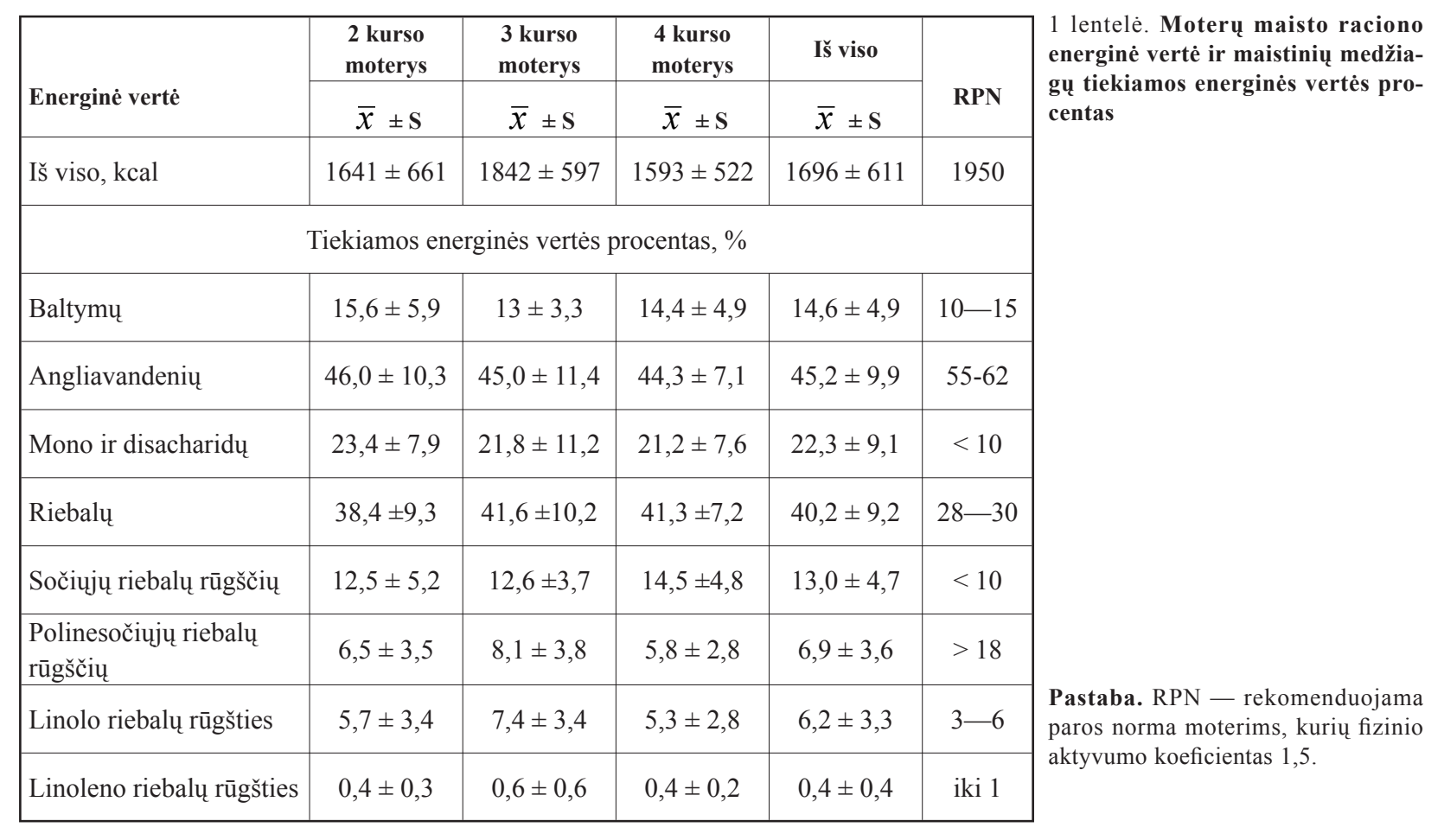

\begin{tabular}{|l|c|c|c|c|c|}
\hline \multirow{2}{*}{ Baltymai } & $\begin{array}{c}\mathbf{2} \text { kurso } \\
\text { moterys }\end{array}$ & $\begin{array}{c}\mathbf{3} \text { kurso } \\
\text { moterys }\end{array}$ & $\begin{array}{c}\mathbf{4} \text { kurso } \\
\text { moterys }\end{array}$ & Iš viso & \multirow{2}{*}{ Norma } \\
\cline { 2 - 5 } Iš viso, g & $\bar{x} \pm \mathbf{S}$ & $\bar{x} \pm \mathbf{S}$ & $\bar{x} \pm \mathbf{S}$ & $\bar{x} \pm \mathbf{S}$ & \\
\hline Valinas, g & $61,6 \pm 26,1$ & $60,5 \pm 21,7$ & $56,5 \pm 20,8$ & $59,9 \pm 23,3$ & 49,00 \\
\hline Izoleucinas, g & $3,14 \pm 1,35$ & $3,15 \pm 1,17$ & $3,02 \pm 1,32$ & $3,1 \pm 1,3$ & 1,60 \\
\hline Leucinas, g & $2,66 \pm 1,16$ & $2,60 \pm 0,99$ & $2,49 \pm 1,05$ & $2,6 \pm 1,1$ & 1,20 \\
\hline Lizinas, g & $4,56 \pm 1,98$ & $4,41 \pm 1,74$ & $4,24 \pm 1,84$ & $4,4 \pm 1,9$ & 2,70 \\
\hline Metioninas, g & $4,08 \pm 2,01$ & $3,94 \pm 1,56$ & $3,71 \pm 1,59$ & $3,9 \pm 1,8$ & 2,50 \\
\hline Treoninas, g & $1,35 \pm 0,65$ & $1,27 \pm 0,51$ & $1,22 \pm 0,52$ & $1,3 \pm 0,6$ & 1,20 \\
\hline Triptofanas, g & $2,28 \pm 1,05$ & $2,32 \pm 0,92$ & $2,19 \pm 0,92$ & $2,3 \pm 1,0$ & 1,30 \\
\hline Fenilalaninas, g & $0,77 \pm 0,33$ & $0,82 \pm 0,33$ & $0,80 \pm 0,38$ & $0,8 \pm 0,3$ & 0,34 \\
\hline
\end{tabular}

2 lentelè. Baltymai ir aminorūgštys moterų maisto racione

su triptofanu - $1: 1,75: 5,3$ (rekomenduojamas $1: 1,5: 4,7)$. Šakotos grandinès aminorūgštys valinas, izoleucinas ir leucinas nesubalansuotos visų kursu studenčiu maiste. Tai nustateme išanalizavę šakotos grandinès aminorūgščių tarpusavio santyki antro $(1: 1,45: 0,8)$, trečio $(1: 1,4: 0,8)$ ir ketvirto $(1: 1,4: 0,8)$ kurso studenčiu maiste. Rekomenduojamas valino, leucino ir izoleucino tarpusavio santykis yra $1: 1,7-2: 0,75-1$.

Nustatème ryši tarp daug baltymų turinčio maisto vartojimo ir studenčių organizmo aprūpinimo mineralinėmis medžiagomis. Kuo mažiau baltyminio maisto moterys vartoja, tuo prasčiau jų organizmas aprūpinamas vitaminu $\mathrm{B}_{12}(\mathrm{r}=0,45$; $\mathrm{p}<0,0001)$, folio rūgštimi $(\mathrm{r}=0,54 ; \mathrm{p}<0,0001)$, kalciu $(r=0,5 ; p<0,0001)$, geležimi $(r=0,45$; $\mathrm{p}<0,0001)$ ir cinku $(\mathrm{r}=0,77 ; \mathrm{p}<0,0001)$.

Angliavandenių kiekis moteru maiste yra nepakankamas (3 lent.). Mono ir disacharidų jų maiste nustatyta dvigubai daugiau $(93,2 \pm 49,4 \mathrm{~g})$ nei rekomenduojama $(\leq 48,8 \mathrm{~g})$, o léčiau skaldomų krakmolo ir kitų polisacharidų kiekis $(100,6 \pm$ $55,5 \mathrm{~g}$ ) per mažas.

Nepakankamas maisto produktų, sudètyje turinčių daug krakmolo ir kitų polisacharidų, kiekis moteru maisto racione yra susijęs su nepakan- 


\begin{tabular}{|c|c|c|c|c|c|c|}
\hline \multirow{2}{*}{$\begin{array}{l}3 \text { lentelè. Angliavande- } \\
\text { niai ir skaidulinès me- } \\
\text { džiagos moterų maisto } \\
\text { racione }\end{array}$} & \multirow{2}{*}{ Angliavandeniai } & $\begin{array}{l}2 \text { kurso } \\
\text { moterys }\end{array}$ & $\begin{array}{l}3 \text { kurso } \\
\text { moterys }\end{array}$ & $\begin{array}{l}4 \text { kurso } \\
\text { moterys }\end{array}$ & Iš viso & \multirow[t]{2}{*}{ RPN } \\
\hline & & $\bar{x} \pm \mathrm{S}$ & $\bar{x} \pm \mathrm{S}$ & $\bar{x} \pm \mathrm{S}$ & $\bar{x} \pm \mathrm{S}$ & \\
\hline \multirow{4}{*}{$\begin{array}{l}\text { Pastaba. RPN - reko- } \\
\text { menduojama paros norma } \\
\text { moterims, kurių fizinio } \\
\text { aktyvumo koeficientas } \\
1,5 \text {. }\end{array}$} & Iš viso, $\mathrm{g}$ & $190,7 \pm 87,2$ & $208,9 \pm 88,2$ & $177,9 \pm 71,7$ & $193,5 \pm 84,1$ & 302,0 \\
\hline & Mono ir disacharidai, $\mathrm{g}$ & $94,4 \pm 42,5$ & $100,0 \pm 61,9$ & $82,6 \pm 40,0$ & $93 \pm 49,4$ & $<48,8$ \\
\hline & $\begin{array}{l}\text { Krakmolas ir kiti } \\
\text { polisacharidai, g }\end{array}$ & $96,9 \pm 60,3$ & $109,1 \pm 50,6$ & $95,3 \pm 54,1$ & $100,6 \pm 55,5$ & - \\
\hline & Skaidulinės medžiagos & $17,0 \pm 8,5$ & $23,0 \pm 10,5$ & $17,9 \pm 9,2$ & $19,3 \pm 9,7$ & $20-30$ \\
\hline \multirow[t]{8}{*}{$\begin{array}{l}4 \text { lentelè. Riebalai mote- } \\
\text { rų maisto racione }\end{array}$} & \multirow[t]{2}{*}{ Riebalai } & $\begin{array}{l}2 \text { kurso } \\
\text { moterys }\end{array}$ & $\begin{array}{l}\text { kurso } \\
\text { moterys }\end{array}$ & $\begin{array}{l}\text { kurso } \\
\text { moterys }\end{array}$ & Iš viso & \multirow{2}{*}{ RPN } \\
\hline & & $\bar{x} \pm \mathrm{S}$ & $\bar{x} \pm \mathrm{S}$ & $\bar{x} \pm \mathrm{S}$ & $\bar{x} \pm \mathrm{S}$ & \\
\hline & Iš viso, $\mathrm{g}$ & $70,2 \pm 34,3$ & $84,9 \pm 35,3$ & $72,8 \pm 24,4$ & $75,8 \pm 32,8$ & 61 \\
\hline & Cholesterolis, g & $0,4 \pm 0,3$ & $0,5 \pm 0,3$ & $0,5 \pm 0,4$ & $0,4 \pm 0,3$ & 0,5 \\
\hline & Sočiosios riebalų rūgštys, $g$ & $22,2 \pm 12,4$ & $25,0 \pm 9,3$ & $25,5 \pm 10,8$ & $24,0 \pm 11,1$ & $<21,7$ \\
\hline & $\begin{array}{l}\text { Polinesočiosios riebalų } \\
\text { rūgštys, g }\end{array}$ & $11,8 \pm 7,6$ & $16,8 \pm 11,1$ & $10,7 \pm 5,9$ & $13,2 \pm 8,9$ & $>39$ \\
\hline & Linolo riebalų rūgštis, $g$ & $10,4 \pm 6,9$ & $15,2 \pm 9,9$ & $9,6 \pm 5,6$ & $11,8 \pm 8,1$ & $6,5-13$ \\
\hline & Linoleno riebalų rūgštis, $g$ & $0,7 \pm 0,5$ & $1,1 \pm 1,6$ & $0,6 \pm 0,4$ & $0,8 \pm 1,0$ & $>2,2$ \\
\hline \multirow[t]{8}{*}{$\begin{array}{l}5 \text { lentelè. Vitaminai mo- } \\
\text { terų maisto racione }\end{array}$} & \multirow[t]{2}{*}{ Vitaminai } & $\begin{array}{l}2 \text { kurso } \\
\text { moterys }\end{array}$ & $\begin{array}{l}3 \text { kurso } \\
\text { moterys }\end{array}$ & $\begin{array}{l}4 \text { kurso } \\
\text { moterys }\end{array}$ & Iš viso & \multirow{2}{*}{ RPN } \\
\hline & & $\bar{x} \pm \mathrm{S}$ & $\bar{x} \pm \mathrm{S}$ & $\bar{x} \pm \mathrm{S}$ & $\bar{x} \pm \mathrm{S}$ & \\
\hline & A $(\text { ret. ekv. })^{1}, \mathrm{mg}$ & $0,68 \pm 0,45$ & $0,70 \pm 0,86$ & $0,80 \pm 0,76$ & $0,72 \pm 0,69$ & 0,80 \\
\hline & $\mathrm{B}_{1}, \mathrm{mg}$ & $1,19 \pm 0,91$ & $1,13 \pm 0,70$ & $1,03 \pm 0,63$ & $1,13 \pm 0,77$ & 1,2 \\
\hline & $\mathrm{B}_{2}, \mathrm{mg}$ & $1,51 \pm 0,97$ & $1,41 \pm 0,81$ & $1,38 \pm 0,76$ & $1,44 \pm 0,86$ & 1,4 \\
\hline & PP (niacin. ekv.) $)^{2}, \mathrm{mg}$ & $16,09 \pm 9,31$ & $14,35 \pm 8,46$ & $11,92 \pm 4,89$ & $14,43 \pm 8,20$ & 13 \\
\hline & C, mg & $80,74 \pm 70,49$ & $110 \pm 107,78$ & $81,53 \pm 70,56$ & $91,00 \pm 85,37$ & 60 \\
\hline & $\mathrm{D}, \mu \mathrm{g}$ & $3,12 \pm 3,50$ & $1,57 \pm 1,49$ & $1,35 \pm 1,51$ & $2,15 \pm 2,63$ & 5 \\
\hline \multirow{4}{*}{$\begin{array}{l}\text { Pastaba. RPN - reko- } \\
\text { menduojama paros norma } \\
\text { moterims, kurių fizinio ak- } \\
\text { tyvumo koeficientas } 1,5 \text {; } \\
\text { retinolio ekvivalentai }{ }^{1} \text {; } \\
\text { niacino ekvivalentai }^{2} \text {; to- } \\
\text { koferolio ekvivalentai }^{3} \text {. }\end{array}$} & E (tok. ekv. $)^{3}, \mathrm{mg}$ & $10,51 \pm 6,68$ & $13,61 \pm 7,43$ & $9,67 \pm 4,71$ & $11,33 \pm 6,67$ & 10 \\
\hline & $\mathrm{B}_{6}, \mathrm{mg}$ & $1,72 \pm 0,84$ & $2,01 \pm 0,95$ & $1,72 \pm 0,86$ & $1,82 \pm 0,89$ & 0,7 \\
\hline & $\mathrm{B}_{12}, \mu \mathrm{g}$ & $3,03 \pm 2,74$ & $2,94 \pm 3,05$ & $2,72 \pm 2,31$ & $2,92 \pm 2,73$ & 3 \\
\hline & Folio rūgštis & $\begin{array}{c}154,04 \pm \\
108,2\end{array}$ & $\begin{array}{c}147,38 \pm \\
77,03\end{array}$ & $\begin{array}{c}124,50 \pm \\
46,43\end{array}$ & $\begin{array}{c}144,19 \pm \\
85,74\end{array}$ & 300 \\
\hline
\end{tabular}

kamu jų organizmo aprūpinimu mineralinėmis medžiagomis - geležimi $(r=0,73 ; p<0,0001)$, magniu $(r=0,63 ; p<0,0001)$, vitaminu $B_{1}$ $(\mathrm{r}=0,65 ; \mathrm{p}<0,0001)$ ir folio rūgštimi $(\mathrm{r}=0,69$; $\mathrm{p}<0,0001)$.

Skaiduliniu medžiagu kiekis antro ir ketvirto kurso studenčiu maiste, sudarantis atitinkamai $17,3 \pm 8,5 \mathrm{~g}$ ir $17,9 \pm 9,2 \mathrm{~g}$, nesiekia minimalaus rekomenduojamo $(20-30 \mathrm{~g})$. Tik trečio kurso moterų maisto raciono skaidulinių medžiagų kiekis $(23 \pm 10,5 \mathrm{~g})$ yra pakankamas.

Visų kursų studenčių maiste riebalų kiekis, vidutiniškai sudarantis $75,8 \pm 32,8 \mathrm{~g}$, viršija rekomenduojamą $61 \mathrm{~g}$ (4 lent.). Iš jų sočiujų riebalų rūgščiu per daug $-24 \pm 11,1 \mathrm{~g}$, o polinesočiujuc riebalų rūgščių $(13,2 \pm 8,9 \mathrm{~g})$ ir linoleno riebalų 


\begin{tabular}{|c|c|c|c|c|c|c|}
\hline \multirow{2}{*}{ Mineralinės medžiagos } & $\begin{array}{l}\text { kurso } \\
\text { moterys }\end{array}$ & $\begin{array}{l}\text { kurso } \\
\text { moterys }\end{array}$ & $\begin{array}{l}4 \text { kurso } \\
\text { moterys }\end{array}$ & Iš viso & \multirow[t]{2}{*}{ RPN } & \multirow[t]{2}{*}{$\begin{array}{l}6 \text { lentelè. Mineralinès } \\
\text { medžiagos moterų mais- } \\
\text { to racione }\end{array}$} \\
\hline & $\bar{x} \pm \mathrm{S}$ & $\bar{x} \pm \mathrm{S}$ & $\bar{x} \pm \mathrm{S}$ & $\bar{x} \pm \mathrm{S}$ & & \\
\hline Natris, mg & $2567 \pm 1632$ & $2461 \pm 1059$ & $2337 \pm 1177$ & $2472 \pm 1341$ & 1500 & \multirow{7}{*}{$\begin{array}{l}\text { Pastaba. RPN - reko- } \\
\text { menduojama paros norma } \\
\text { moterims, kuriu fizinio } \\
\text { aktyvumo koeficientas } \\
1,5 \text {. }\end{array}$} \\
\hline Kalis, mg & $2564 \pm 1296$ & $2883 \pm 1389$ & $2545 \pm 1556$ & $2666 \pm 1395$ & 2500 & \\
\hline Kalcis, mg & $681 \pm 297$ & $648 \pm 318$ & $669 \pm 505$ & $667 \pm 365$ & 1000 & \\
\hline Magnis, mg & $240 \pm 147$ & $252 \pm 123$ & $210 \pm 122$ & $236 \pm 133$ & 300 & \\
\hline Fosforas, mg & $989 \pm 381$ & $994 \pm 347$ & $954 \pm 439$ & $981 \pm 383$ & 900 & \\
\hline Geležis, mg & $14 \pm 8$ & $15 \pm 7$ & $13 \pm 6$ & $14 \pm 7$ & 15 & \\
\hline Cinkas, $\mu \mathrm{g}$ & $7295 \pm 3224$ & $8918 \pm 3590$ & $7361 \pm 3287$ & $7857 \pm 3425$ & 12000 & \\
\hline
\end{tabular}

rūgšties $(0,8 \pm 1,0 \mathrm{~g})$ trūksta. Nepakeičiamos, organizme nesintezuojamos linolo ir linoleno riebalu rūgštys studenčių maisto racione yra nesubalansuotos. Tai patvirtina linolo ir linoleno riebalų rūgščiu tarpusavio santykis antro, trečio ir ketvirto kurso studenčių maiste, sudarantis atitinkamai $1: 14,8$, $1: 13,8$ ir $1: 16$ (rekomenduojamas $1: 5$ ).

Ivertinus studenčiu maisto raciono vitaminu sudèti (5 lent.) nustatyta, kad antro kurso studenčių maiste trūksta vitaminų $A, D$, folio rūgšties, trečio kurso - vitaminu $A, B_{1}, D, B_{12}$, folio rūgšties ir ketvirto kurso - vitaminu $\mathrm{B}_{1}, \mathrm{PP}, \mathrm{D}, \mathrm{E}, \mathrm{B}_{12}$, folio rūgšties.

Studijuojančių moterų organizmo aprūpinimas mineralinėmis medžiagomis yra nepakankamas (6 lent.). Nepriklausomai nuo studijų kurso jų maiste trūksta mineralinių medžiagu kalcio, magnio ir cinko, o antro ir ketvirto kurso moteru maiste nustatytas ir geležies trūkumas. Mineralinès medžiagos studenčių maiste yra nesubalansuotos. Antro kurso moterų maiste fosforo ir kalcio tarpusavio santykis $-1: 1,45$, trečio $-1: 1,53$, ketvirto - $1: 1,42$ (norma: $1: 1,1$ ). Magnio ir kalcio tarpusavio santykis antro kurso studenčiu maiste $-1: 0,35$, trečio $-1: 1,38$ ir ketvirto $1: 0,31$ (norma: $1: 0,5$ ). Nors maisto racione natrio ir kalio kiekis artimas rekomenduojamai paros normai, šios mineralinès medžiagos nesubalansuotos - jų tarpusavio santykis antro, trečio ir ketvirto kurso studenčiu maiste sudaro atitinkamai $1: 1,1: 1,85$ ir $1: 0,92$ (norma: $1: 1,7$ ).

\section{REZULTATŲ APTARIMAS}

Ištyrus Vilniaus universiteto Sveikatos ir sporto centre organizuotoje fizineje veikloje dalyvaujančių studenčių mitybą nustatėme, kad jų organizmo aprūpinimas energija ir pagrindinèmis maistinėmis medžiagomis neatitinka rekomendacijų. Mūsų tirtų studenčių mitybos rezultatus palyginus su kitų autorių (Stukas, 2009) gautaisiais nustatyti panašūs mitybos ypatumai. Ir anksčiau tirtų studenčiu maisto raciono energinè vertè $(1342 \pm 150 \mathrm{kcal})$, ir mūsų tirtujų (1696 \pm $611 \mathrm{kcal})$ nesiekia rekomenduojamos. Tačiau organizuotoje fizinejje veikloje dalyvaujančiu moteru maisto raciono kaloringumas didesnis. Lankant fizinès veiklos pratybas, organizmo paros energijos sąnaudos yra didesnès nei mažiau fiziškai aktyvių moterų. Organizuotas fizinès veiklos pratybas lankančių studenčių organizmo poreikis angliavandeniams padideja (Burke, Deakin, 2002), nes per ilgesnes nei 35 minučiu trukmès pratybas daugiausia lavinama aerobinè ištvermè, ir energija organizme gaminama iš angliavandenių aerobiniu būdu (Skernevičius ir kt., 2002), tačiau mes nustatėme, kad šias pratybas lankančiu studenčių maiste angliavandenių trūksta.

Galima daryti prielaidą, kad dalis tirtų studenčių, norèdamos sumažinti kūno masę, menkesnès energinès vertès mitybą derina su organizuotomis fizinès veiklos pratybomis. Tai patvirtina jų maisto raciono per maža energinè verte ir pagrindiniu maistinių medžiagų disbalansas. Mažindamos maisto raciono kaloringuma, studentės labai apriboja maisto produktu, kurių sudètyje daug angliavandeniu, mono ir disacharidų, riebalų vartojimą. Respondenčių maiste nepakanka mono ir disacharidu, krakmolo ir kitu polisacharidu dèl mažesnio duonos ir batono kepinių, miltinių, ivvairių grūdu produktų, vaisių, saldumynų, ankštinių daržovių vartojimo.

Organizuotą fizinę veiklą lankančių studenčių maiste trūksta vitaminų $\mathrm{A}, \mathrm{D}, \mathrm{B}_{1}, \mathrm{~B}_{12}, \mathrm{E}, \mathrm{PP}$, folio 
rūgšties, mineralinių medžiagų kalcio, magnio cinko ir geležies. Mūsų tirtų studenčių maisto raciono vitaminų ir mineralinių medžiagų sudetti palyginę su kitų autorių tyrimų duomenimis, nustatėme daug panašumų — pastarųjų, kaip ir mūsų tirtujų, maiste trūksta mineralinių medžiagu kalcio, magnio, cinko, vitaminu $\mathrm{A}, \mathrm{D}, \mathrm{B}_{1}, \mathrm{PP}, \mathrm{B}_{2}$, $\mathrm{E}, \mathrm{B}_{12}$ ir folio rūgšties. Vitaminų ir mineraliniu medžiagu trūkumas būdingesnis organizuotos fizinès veiklos pratybas lankančioms studentems, kurių maisto racione yra per mažai krakmolo ir kitų polisacharidų, skaidulinių medžiagų (ivairių grūdinių produktų, duonos ir batono kepinių, šviežių vaisių ir daržovių) ir daug baltymų (mèsos, žuvies, pieno produktų: pieno, varškès, varškès sūrio, jogurtų, rūgpienio, kefyro) turinčiu maisto produktų. Mūsų tyrimo duomenys apie vartojamų maisto produktų asortimenta sutampa su kitų mokslininkų (Laskienè ir kt., 2009) gautaisiais, nurodančiais, kad studentai per mažai valgo šviežių daržovių ir vaisių, pieno, mèsos ir žuvies produktų.

Apibendrinant galima teigti, kad organizuota fizinè veikla daro įtaką studenčių mitybai - ju maisto raciono energinè vertè yra per maža, tačiau didesnè nei organizuotas fizinès veiklos pratybas nelankančių studenčių. Kadangi studenčių maisto raciono angliavandenių kiekis yra per mažas, riebalų - per didelis, trūksta kai kurių vitaminų ir mineralinių medžiagų, galima konstatuoti, kad sveikatos ir sporto centre organizuotas fizinès veiklos pratybas lankančios studentès fizini aktyvuma ir mitybą derina netinkamai.

\section{IŠVADOS}

Studenčiu maisto raciono energinè vertè yra per maža, palyginus su rekomenduojama paros norma. Maistinès medžiagos nesubalansuotos per didelę tiekiamos energinès vertès dalį sudaro riebalai, per mažą - angliavandeniai.

Baltymų kiekis studenčių maiste patenkina jų organizmo poreikị, tačiau šakotos grandinès nepakeičiamos aminorūgštys valinas, leucinas ir izoleucinas jų maisto racione yra nesubalansuotos. Antro kurso studenčių maisto racione nesubalansuotos ir aminorūgštys metioninas bei lizinas.

Organizuotas fizinès veiklos pratybas lankančių Vilniaus universiteto studenčių maisto racione trūksta mineralinių medžiagų kalio, magnio, cinko, geležies, vitaminų $\mathrm{A}, \mathrm{D}, \mathrm{B}_{1}, \mathrm{~B}_{12}, \mathrm{E}, \mathrm{PP}$ ir folio rūgšties.

\section{LITERATŪRA}

Baranauskas M., Tubelis L., Stukas R., Švedas, E. (2009). Lietuvos olimpinio sporto centro sportininkų mitybos tyrimas. Sporto mokslas, 3 (57), 40-48.

Burke, L., Deakin, V. (2002). Clinical Sports Nutrition. Australia. P. 90-117.

Laskienė, S., Kemerytė-Riaubienè, E., Vizbaraite, D., Šertvytienè, D. (2009). Lietuvos kūno kultūros akademijos pirmojo kurso studentu mitybos ypatumai. Sporto mokslas, 3 (57), 48-55.

Maskeliūnas, J., Stukas, R., Mačytė, L. (1996). Studentų mediku mitybos ypatumai 1990-1994 metais. Medicina, 32 (7), 693-700.

Rekomenduojamos paros maistiniu medžiagu ir energijos normos. (2002). Vilnius.

Skernevičius, J., Raslanas, A., Dadelienė, R. (2002). Ištvermès vertinimas. Kn. Sporto mokslo tyrimu metodologija (pp. 126-137). Vilnius.

Stukas R., Dobrovolskij, V. (2009). Visuomenès sveikatos studentu mitybos ypatumai. Sveikatos mokslai, 1, 2147-2153.
Stukas, R., Pečiukonienė, M., Kemerytė-Riaubiene, E., Baškienè, V. (2009). Kai kurie riebalų apykaitos sportininku organizme ypatumai. Sporto mokslas, 2 (56), 44-49.

Stukas, R., Šurkienè, G., Pazdrazdyte, R. (2000). Studentuc mediku mitybos ypatumai. Visuomenès sveikata, 1 (11), $56-63$.

Stukas, R., Šurkienė, G. (1999). Studentų medikų mitybos aspektai. Kn.: Aktualūs medžiagu apykaitos klausimai: Šeštosios mokslinès konferencijos, ivykusios $1999 \mathrm{~m}$. gegužés 25-27 d. Vilniaus pedagoginiame universitete, medžiaga (pp. 489-492). Vilnius.

Sučilienè, S., Abaravičius, A., (2002). Maisto produktu sudètis. Vilnius. P. $10-315$.

Škèmienė, L., Ustinavičienė, R., Piešinė L., Radišauskas, R. (2007). Studentų medikų mitybos ypatybès. Medicina, 2, 145-152. 


\title{
SOME ASPECTS OF NUTRITION OF VILNIUS UNIVERSITY FEMALE STUDENTS PARTICIPATING IN ORGANISED PHYSICAL ACTIVITIES
}

\author{
Laimutè Samsoniené $^{1}$, Ramunė Žilinskiené ${ }^{1}$, Marius Baranauskas ${ }^{1,2}$, Rimantas Stukas ${ }^{1}$ \\ Vilnius University', Vilnius, Lithuanian Olympic Centre of Sport ${ }^{2}$, Vilnius, Lithuania
}

\begin{abstract}
The aim of this research was to study and evaluate nutrition of Vilnius University female students of 2nd, 3rd and 4th years participating in organised physical activities. We evaluated nutrition of 128 female students of Vilnius University who had chosen „Introduction into PE and healthy lifestyle“ as an optional subject. Method of one day (24 hours) nutrition survey was applied in this research. Chemical composition and energetic value of food ration was counted using tables of chemical composition of nutrition products. Statistical analysis was carried out using software for statistical data processing SPSS v.13. The methods of mathematical statistics were applied for the analysis of research data: arithmetic means $(\bar{x})$ were calculated and data dispersion was evaluated under standard deviation (S). Pearson's correlation coefficient (r), when $\mathrm{p} \leq 0.05$, was employed in the calculations aiming to get more accurate data and searching for statistical correlation links among variables.

Research data were compared to recommended norms (per day) of nutrients and energy norms.

Research results have demonstrated that energetic value obtained by students with food (1696 \pm $611 \mathrm{kcal})$ was too low comparing to recommended $(1950 \mathrm{kcal})$. Energetic food rations values of secondand fourth-year students were particularly low in a number of cases; in individual cases it hardly reached $586 \mathrm{kcal}$ for second-year students and $663 \mathrm{kcal}$ in fourth year students.

In main nutrients in female students' nutrition were not balanced. They used too much fat and not enough carbohydrates. Immoderate amount of provided energetic value - consisted of fats $(40.2 \pm 9.2 \%)$, saturated fatty acids $(13 \pm 47 \%)$, linol fatty acid $(6.2 \pm 3.3 \%)$, mono- and disaccharides $(22.3 \pm 9.1 \%)$; and too small amount - of carbohydrates $(45.2 \pm 9.9 \%)$ which consisted of starch, other polysaccharides and polyunsaturated fatty acids $(6.9 \pm 3.6)$ such as non-synthesized linolenic fatty acid $(0.4 \pm 0.4)$.

Amount of proteins in the daily ration of female students - participants of our study - corresponded to recommended norms per day. Essential amino acids valine, leucine and isoleucine were not balanced in the nutrition of the students in all years of studies. In the ration of second-year students amino acids methionine and lizine were not balanced. In the daily ration of the female students there was a shortage of food rich in starch and other polysaccharides, fibres (different cereal products, breads, fresh fruits and vegetables) and foods rich in proteins (meat, fish, milk products), and thus they do not get enough minerals such as potassium, magnesium, zinc, iron and vitamins $\mathrm{A}, \mathrm{D}, \mathrm{B}_{1}, \mathrm{~B}_{12}, \mathrm{E}, \mathrm{PP}$ as well as folic acid. Thus we may conclude that female students attending organised PE activities incorrectly combine physical activity and nutrition.
\end{abstract}

Keywords: food ration, nutrition, physical activity, energetic value, fats, carbohydrates, proteins, vitamins, minerals.

Gauta 2010 kovo 15 d.

Received on March 15, 2010

Laimutė Samsonienè

Vilniaus universitetas

(Vilnius University)

Saulètekio al. 2, LT-10222 Vilnius

Lietuva (Lithuania)

Tel 861252003

E-mail laimute@dalila.lt 